\title{
ANALYSIS OF THE ABILITIES OF TERBUKA UNIVERSITY STUDENTS IN SUMMARY OF MODULE YEAR 2020/2021 (Study of Student of Science Semester 1 UT Medan)
}

\author{
Kula Ginting 1
}

Open University, Indonesia

Email : kulaginting@ecampus.ut.ac.id

\begin{abstract}
The problem examined in this study is to determine the ability of UT students to summarize a reading in the lecture module. The problem that arises is the lack of students' ability to summarize the module. The population in this study were all 1st semester PGSD students in the field of UT Medan. This type of research is quantitative research in which this research is used to examine a particular population or sample, with sampling generally carried out randomly, data collection using research instruments, data analysis is quantitative or statistical in order to test the hypothesis that has been applied.
\end{abstract}




\section{A. Introduction}

Education is one of the levels that a person must take in order to improve his standard of living. Education is also a place where a child can develop his or her potential towards maturity, through education a child can find new things and be able to know and develop his talents. According to Tarigan (2005: 1) there are four components of language skills, namely: 1 . Listening skills; and 2. speaking skills; 3 . Reading skills; and 4. Writing skills. Each of these skills is closely related to the other three skills in various ways.

Summarizing material looks easy, but is actually very difficult if we don't have the tricks. Many students only summarize what is in the book or module. Given that summarizing is an activity that is quite often carried out by UT students because of the thick and also the meetings are very short. By summarizing a reading in language appropriately and creatively, it can be increased, besides that by summarizing a reading it can increase one's sensitivity and ability to enjoy a summary in a reading. Therefore, researchers are interested in making research entitled analysis of the ability of Open University students in summarizing the 2020/2021 TA module.

\section{Theoritical review}

1. Student Ability Analysis

Understanding is a process of thinking and learning. It is said so because to get to understanding it needs to be followed by learning and thinking. Understanding is a process, an act and a way of understanding. Ability can also be called competence. The word competence comes from the English word "competence" which means ability, power, authority, skill, knowledge, and proficiency, ability and authority. So the word competence is from the word competent which means having the ability 
and skills in their field so that they have the authority or authority to do something within the limits of their knowledge. The scope of ability is quite broad, including activities in the form of actions, thinking, speaking, seeing and so on. However, in the narrow sense, ability is usually shown more to activities in the form of actions. So ability is the basic potential that students who study the scope of material in a lesson need to have at a certain level. From these definitions it can be concluded that ability is the ability or ability of an individual to master a skill and is used to carry out various tasks in a job.

2. Summarize

Dalman (2015: 206) states that a summary is a result of writing that summarizes the text that is read in the author's own language. The summary is the result of summarizing activities. A summary can also be interpreted as the result of assembling or unifying the main points of the discussion. The thing that must be considered in making the summary is the use of the language used in the summary. The language of the summary must be different from the original language of the author of the book being summarized. Summary features should be concise, clear and concise. In order for your summary to be good, there are steps you need to pay attention to. The steps to summarize are as follows. a) Read the original text or manuscript b) determine and record the main ideas $c$ ) start writing the summary d) reread the summary that has been made.

Summarizing is shortening the writing or written text while maintaining the original writing of the author. Summarizing the function is to find out the main idea or main ideas of the author and the author's goals in writing his writing. The summary writer must make the original writing of a text without subtracting every word or letter from the main idea being summarized. Summarizing or summarizing is an effort to understand the [826] 
text. A person will have difficulty summarizing a text if he does not understand the text to be summarized. Therefore, it is important to note when summarizing a text is to understand the contents of the text in question.

3. How to make a summary

For people who are used to making summaries, maybe the rules that apply in compiling summaries have been embedded in his mind. However, of course it is necessary to provide some benchmarks as a guide in making a summary, especially if they are just starting out or have never made a summary.

According to Encep (Dalman 2015: 218) summary preparation procedures can be classified into two categories, namely, (a) general procedures, (b) special procedures. General procedures are general work steps and apply to the preparation of a summary and synonyms, such as an overview, synopsis, summary, abstract, and paraphrase. Meanwhile, special procedures are work steps that are specific to the creation of a form of compaction, abbreviation, or re-expression of one particular article in a certain connotation and context. The general procedure in summarizing a summary is basically divided into four steps, namely reading, selecting, writing, and comparing.

The next step is to compare the summary results with the original text. The things that need to be considered in this step are:

a. The main content of the reading is reproduced in its own language.

b. If you want to include an explanatory mind, then the explanatory mind in question must be truly selected, that is, the one that gives meaningful support to the mind

c. Should not include other thoughts outside the original thought of the writing. 
After carrying out the four steps above, according to Encep in Dalman (2015: 220), there are several things that need to be considered so that the summary is accepted as good writing.

a) Summarize in single sentences rather than compound sentences.

b) Summary sentences into phrases, phrases into words. If the summary is long replace it with a central idea only.

c) The size of the summary depends on the number of paragraphs and the main topics to be included in the summary.

d) If possible, discard all existing adverbs or adjectives, although sometimes an adjective or adverb is retained to explain the general idea implied in the dependent chain or adjective sequence contained in the text.

e) Maintain the order of ideas and order of the script.

f) In order to distinguish between a summary of an ordinary writing and a lecture that uses a singular or plural first-person perspective, the summary of the speech or lecture should be written in third person.

g) In a summary the length is also determined. If asked to make a summary to be one hundredth of the original essay, then it must do so. If you summarize a book that is 250 pages thick into one tenth, the calculation is as follows: a. the length of the original essay (in the form of words) is: number of pages $x$ number of lines per page $x$ number of words per line $=250 \times 35 \times 9$ words $=78,750, b$. The length of the summary in the form of the number of words is: 78,750: $10=7,875$ words The aspects of the assessment of the skills to summarize the contents of the story read are:

1) The suitability of the summary with the contents of the book

2) Use of Indonesian,

3) Presentation of storylines or story writing systematics 


\section{B. Method}

This research is a qualitative research, so the researcher will use the following data collection techniques:

\section{Test}

According to Arikunto (2013: 266), "Tests are questions or exercises and other tools used to measure skills, knowledge, intelligence, abilities or talents possessed by individuals or groups". The test assigns students to find out the ability of students to summarize a reading, students are assigned to read a reading text entitled "Lucky Corn Farmers" after students read it the students make a summary of the reading. The summary results are given a score of 1-5.

\section{Data analysis technique}

Sugiyono (2009: 244) states that "Data analysis is the process of systematically searching and compiling data obtained from interviews, field notes, and documentation by organizing data into categories, describing them into units, and arranging them into patterns, selecting which ones are important and which ones will be studied and make conclusions so that it makes it easier for each other to be understood by oneself and others. The steps taken to analyze the research data were: 1) After the students 'answer sheets were collected, corrections were made, then they were given a score, 2) Finding the average value of the students' ability.

Looking for the student's ability to determine the student's ability to summarize by finding the student's overall average using the formula:

$$
\begin{aligned}
& \bar{x}=\frac{\sum_{\text {fixi }}}{\sum_{f i}} \quad \text { (Sudjana 2016: 67) } \\
& \text { Information: } \\
& \bar{x}=\text { Mean (average) }
\end{aligned}
$$




$$
\begin{aligned}
& \Sigma_{f i}=\text { Number of values (frequency) } \\
& \Sigma_{\mathrm{xi}}=\text { Value }
\end{aligned}
$$

The average value is then converted to the criteria for student understanding using the following criteria table:

\begin{tabular}{ll}
\hline \multicolumn{1}{c}{ Score Value } & \multicolumn{1}{c}{ Criteria } \\
\hline $81-100$ & Very good \\
\hline $61-80$ & Good \\
\hline $41-60$ & Enough \\
\hline $21-40$ & Less \\
\hline $0-20$ & Very less \\
\hline
\end{tabular}

\section{Finding and Discussion}

\section{Description of Research Implementation}

1. Description of Research Implementation

This implementation is carried out on 1st semester students of PGSD Field of Science, Medan Open University. This study aims to determine the ability to summarize student modules, by providing subject modules to students for summarization.

2. Description of Research Results

The description of the test data research that has been carried out is as follows. Presentations on the student test are instructed to make a summary of the modules that have been distributed to each student. The test data processing uses the formula:

$$
\text { acquisition value }=\frac{\text { total assessment score }}{\text { maximum score }} \times 100
$$

\section{Data on the Ability of Students' Ability Test to Summarize a Reading}

To find out the student's ability to summarize the module, the following data were obtained. 


\begin{tabular}{lllll}
\hline No. & Score & Frequency & Percentage & Information \\
\hline 1 & $81-100$ & 0 & $0 \%$ & Very good \\
\hline 2 & $61-80$ & 0 & $0 \%$ & Good \\
\hline 3 & $41-60$ & 13 & $52 \%$ & Enough \\
\hline 4 & $21-40$ & 11 & $44 \%$ & Less \\
\hline 5 & $0-20$ & 1 & $4 \%$ & Very less \\
\hline & $\Sigma$ & 25 & $100 \%$ & \\
\hline
\end{tabular}

Based on the data obtained, the number of respondents is in the very category either 0 people or $(0 \%)$, good $0(0 \%)$, just 13 people $(52 \%)$, less 11 people (44\%), and very less 1 person (4\%).

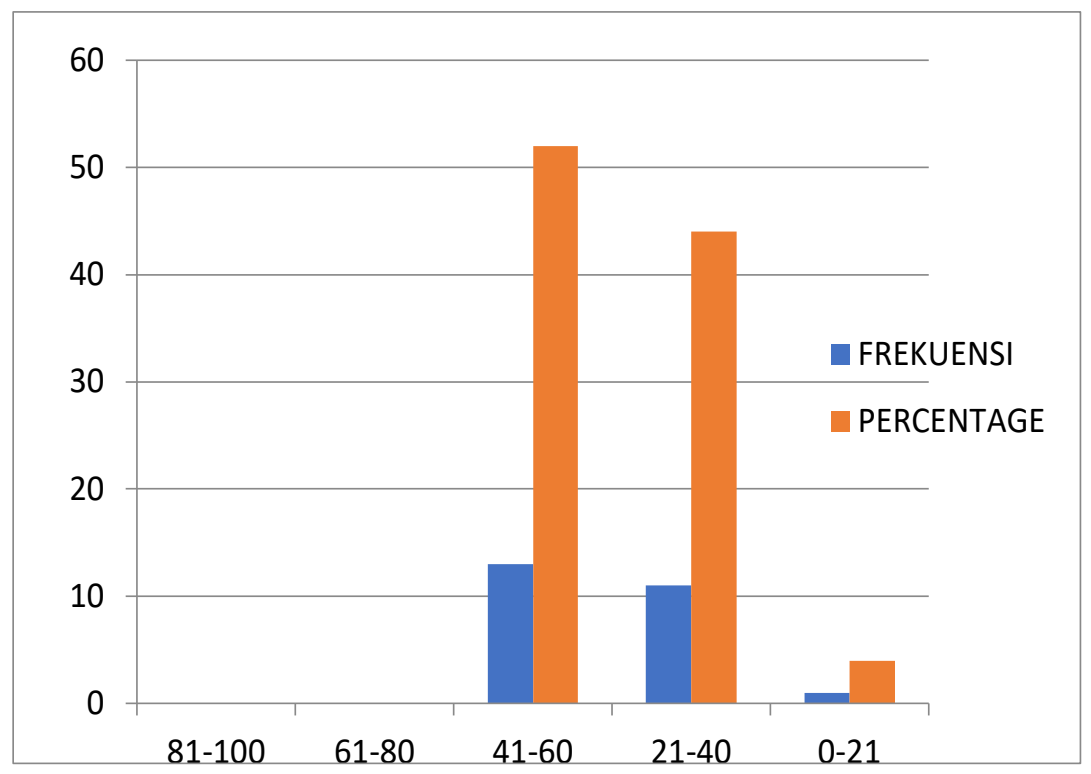

Figure 1. Diagram of Student Test Results in Analyzing Students's Ability to Summarize a Reading UPT SD Negeri 060930 Medan Johor 


\section{Conclusion}

This research was conducted on UT students in the field of Elementary School Teacher Education Semester 1. This research was conducted to determine the ability to summarize student modules to a reading. To answer the research questions that have been formulated, the researcher used a data collection tool in the form of a test. After conducting research and analyzing the results of student tests, the overall average score of students' ability to summarize a reading was 42.24. Based on this average value, the ability of students to summarize a reading is sufficient to meet the criteria. From the test results, the writer can conclude that the students' ability to summarize is quite good, but most students have difficulty in summarizing a reading because students onlyfocus on reading without understanding the content of the reading.

\section{Bibliography}

Arikunto, Suharsimi. 2013. Prosedur Penelitian: Suatu Pendekatan Praktik. Jakarta: Rineka Cipta.

Dalman. (2015). Menulis karya ilmiah. Depok: Rajagrafindo Persada.

Sudjana, Nana. (2016). Penilaian Hasil Proses Belajar Mengajar. Bandung: PT REMAJA ROSDAKARYA.

Sugiyono, 2009, Metode Penelitian Kuantitatif, Kualitatif dan R\&D, Bandung : Alfabeta.

Tarigan, Henry Guntur. 2005. Keterampilan Menulis. Bandung. Angkasa W. J. S. Porwadarminta, Kamus besar Bahasa Indonesia (Jakarta: Balai Pustaka, 1991), h. 636 